\title{
Climate Change Impact in Flores Island, a Dry Region in Indonesia
}

\author{
Kusumastuti, C. ${ }^{*}$, Gode, D. ${ }^{1}$, Kurnianto, Y.F. ${ }^{1}$, and Syaranamual, F.J. ${ }^{1}$
}

\begin{abstract}
Climate change impacts have gained great attention to be studied in various fields. In this paper, an investigation of rainfall pattern change is performed using three statistical methods, i.e., simple linear regression, t-test, and Mann-Kendall's test. The analysis is performed at 10- and 20-year time scales of daily, monthly, and annual rainfall in Flores Island, a dry region in Indonesia. In general, an increasing monthly rainfall trend is detected in the rainy season (October - April) at a 20-year period, using all three methods. Specifically, a significant increasing trend in March 1989 - 2008 is observed, and it contributes to the significant increasing trend of annual rainfall. The findings presented in this paper should be an alert for potential climate change impacts in the region. The positive consideration of having more rainfall in a dry region might turn into a negative reality when adaptation measures are not well-prepared.
\end{abstract}

Keywords: Climate change; dry region; Mann-Kendall's test; rainfall trend; t-test.

\section{Introduction}

Potential impacts of climate change in various fields have gained a great deal of attention to be studied worldwide. A comprehensive review of climate change impacts on hydrological variables by Intergovernmental Panel on Climate Change (IPCC), presented in the $2^{\text {nd }}[1]$ and the $4^{\text {th }}$ assessment reports $[1,2]$. Among other hydrological variables, precipitation has received more attention to be studied further. The increased temperature leads to the increased precipitation which may cause further impacts to other hydrological variables. Following the assessment reports, numerous studies on regional rainfall pattern change had been performed [3-11].

A spatial difference of change of temperature and precipitation across Canada catchments had caused the non-uniform changes of hydrological variables, such as monthly runoff in the region [4]. The findings provide additional knowledge on the change of climate variables after a prior study identified the increasing trend of temperature and precipitation in the $20^{\text {th }}$ century across Canada [11]. An increase of heavy rainfall is also identified in some parts of Western Australia which on the contrary, in the other region of Australia, the Queensland coast, experienced a declining trend of extreme rainfall during summer and autumn [12].

${ }^{1}$ Department of Civil Engineering, Petra Christian University, Л. Siwalankerto 121-131, Surabaya 60236, INDONESIA

*Corresponding author; Email: cilcia.k@petra.ac.id

Note: Discussion is expected before July, $1^{\text {st }} 2021$, and will be published in the "Civil Engineering Dimension", volume 23, number 2, September 2021.

Received 08 January 2021; revised 17 January 2021; accepted 24 January 2021.
A study in a semi-arid region in Africa contributed to the knowledge of precipitation change has occurred globally at a different rate [13]. The increasing subdaily rainfall and annual rainfall has been detected in Sahel, Africa. These observations revealed a contrary condition of other regions in Africa which experienced a decreasing trend of precipitation during the $20^{\text {th }}$ century $[3,10]$.

Using daily temperature and precipitation data from 91 stations in 15 countries in Southeast Asia and the South Pacific, an upward trend of precipitation is observed. On the contrary, a declining trend of extreme rainfall is detected in the region [8]. In accordance with the study, an increasing trend of daily, monthly, and annual rainfall in the Bangkok Metropolitan Administration, Thailand has been detected [7]. The increasing extreme rainfall during the rainy season has contributed to the total annual rainfall in the country [14]. In the same paper, the authors described a similar increasing trend of total annual rainfall and extreme rainfall in Jakarta, Indonesia.

In this study, rainfall pattern change in a dry region in Indonesia is investigated as an initial stage of climate change impacts studies in the region. A brief description of the study area, collected data, and the methods which are employed to perform the trend analysis are presented in the next section followed by results and discussions, and the conclusions are presented in the last section.

\section{Data and Methods}

\section{Data}

Indonesia consists of more than thirteen thousand islands which are interconnected by seas and straits [15]. The average annual rainfall in the country 
ranges from 2000-3000 mm. Among four archipelagos in the country, Nusa Tenggara Archipelago, specifically East Nusa Tenggara Province, Indonesia, experienced the smallest number of rain days of 84 days which contributed to $954.6 \mathrm{~mm}$ of annual rainfall in 2019 [16]. The long history of less rainfall in the province compared to the other provinces makes the province is known as one of the dry regions in the country. Considering the potential negative impacts of climate change in the province, an initial study of rainfall trend analysis in one island, namely Flores Island, is presented in this paper.

Daily rainfall data analysed in this paper are collected from three meteorological stations operated by Meteorological, Climatological, and Geophysical Agency of Indonesia (BMKG), located in Manggarai Barat Regency, Sikka Regency, and Flores Timur Regency (1 to 3 at Figure 1, upper image). A complete record of daily rainfall from 1979 until 2018 in Sikka Regency is available to be analysed. On the other hand, a shorter record, from 1998 to 2016, is available in the other two rainfall stations. The average value of daily, monthly, and annual rainfall from the three rainfall stations is analysed to represent the change of rainfall pattern in the whole island.
Specifically, in Sikka Regency, located in the centre of Flores Island, more number of rainfall stations are operated by Agriculture department of Sikka Regency (4 to 12 at Figure 1, lower image). It is expected that by considering a greater number of rainfall stations, the average value of rainfall will provide a better representation of the region. Therefore, a detail study is performed in Sikka Regency.

A complete record of daily rainfall is expected to maintain the continuity of the datasets for the trend analysis. Therefore, an assessment of the quality of the datasets by identifying the number of missing daily rainfall data is performed at the initial stage of the research. Once, the missing data is identified, it is then filled by using daily rainfall data from two nearest rainfall stations to the station with the missing data. Arithmetically, when the rainfall stations with some missing daily data having more than $10 \%$ different of normal annual precipitation (regardless the year with missing data) than the normal annual precipitation of other rainfall stations with complete data, the missing daily data is estimated by taking the average value of rainfall from the other stations. The average value is estimated after giving weights by the normal annual

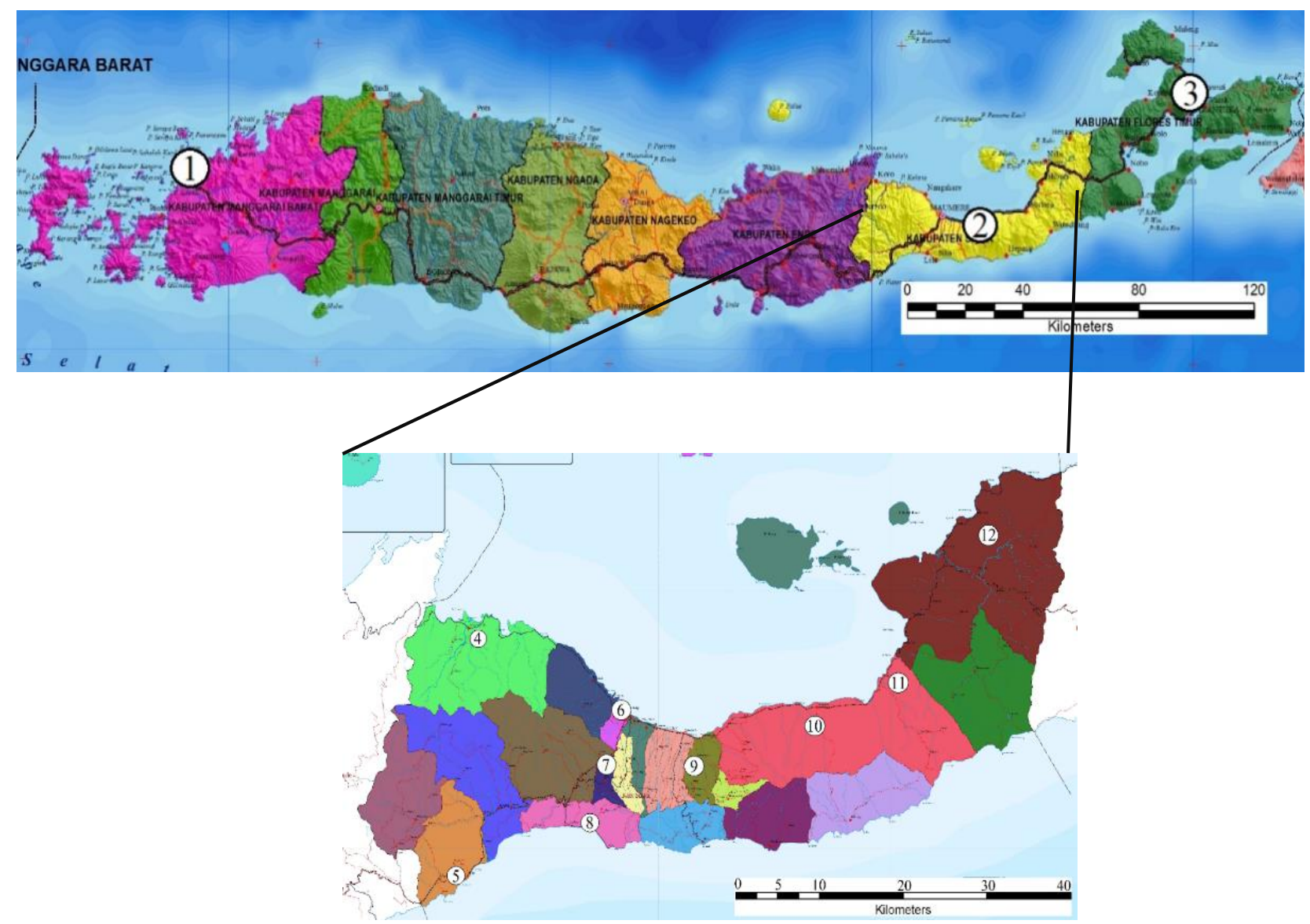

Figure1. Rainfall Stations Map of Flores Island: (1) - (3) operated by BMKG, (4) - (12) operated by Agriculture Department of Sikka Regency 
precipitation of the associated stations. Otherwise, it is simply an arithmetic average value from the daily rainfall data at the nearest rainfall stations.

\section{Methods}

Three statistical methods, namely, simple linear regression, t-test, and Mann-Kendall's test are used to investigate the daily, monthly, and annual rainfall trend in Flores Island. Despite the simplicity of the three methods, all together is expected to provide a clear overview of the rainfall pattern change in the island. The linear regression model until very recently is still being used in hydrology studies to observe the hydrological variation in time [17-19]. The method attempts to explain the relationship between two variables using a straight line. A numerical measure of the relationship between the two variables, called the correlation coefficient, $R^{2}$, ranges from -1 to +1 , giving very strong negative and positive relationship [20]. Generally, the model is described by the following equation,

$y=m x+C$

where $\boldsymbol{y}$ is the dependent variable, $\boldsymbol{x}$ is the independent variable, $\boldsymbol{m}$ is the slope of the line and $\boldsymbol{C}$ is the intercept constant.

The observation of the stability of mean of a hydrological variable can be used to provide information on hydrological variation in a particular region. The commonly used method to perform the analysis of the stability of mean is t-test $[7,9,10,21,22]$. The main procedure of $t$-test is the estimation of $t$-value between two datasets with an equal sample size and comparing the obtained t-value to the t-critical value. The calculation of $t$-value of rainfall datasets with equal sample sizes and similar variances can be performed using Equation (2).

$t=\frac{\overline{x_{1}}-\overline{x_{2}}}{s_{p} \sqrt{\frac{1}{n_{1}}+\frac{1}{n_{2}}}}$

for,

$s_{p}=\sqrt{\frac{\left(n_{1}-1\right) s_{x_{1}}^{2}+\left(n_{2}-1\right) s_{x_{2}}^{2}}{n_{1}+n_{2}-2}}$

where, $\overline{\boldsymbol{x}}$ is the mean of the dataset, $\boldsymbol{s}$ is the standard deviation of the dataset, and $n$ is the size of the dataset.

The rank-based Mann-Kendall's test is a nonparametric test widely used for analysing trend present is hydrological variables time series $[4,7,14$, 18,21-26]. No assumption of the underlying distribution of the hydrological variables time series is needed when performing Mann-Kendall's test. This advantage is the fundamental reason to choose the method in most hydrology studies. The MannKendall's statistics is given as follows,
$S=n_{c}-n_{d}$

where $n_{c}$ and $n_{d}$ is the total score of concordant and discordant pairs respectively. A positive value of $S$ indicates an increasing trend underlying in the time series while a negative value indicates a decreasing trend. Since the null hypothesis of Mann-Kendall's is no trend, $S$ is equal to zero in the initial stage. It is incremented by 1 if the data value in subsequent time series is higher than the previous data, called the concordant pair, and -1 if it is lower, called the discordant pair.

The statistical significance of the trend can be determined by estimating the $\mathrm{z}$-value using Equation (5) and then comparing it to the z-critical value of normal distribution.

$z=\left\{\begin{array}{cl}\frac{S-1}{\sigma_{s}} & \text { if } S>0 \\ 0 & \text { if } S=0 \\ \frac{S+1}{\sigma_{s}} & \text { if } S<0\end{array}\right.$

for,

$\sigma_{s}=\sqrt{\frac{n \cdot(n-1) \cdot(2 n+5)}{18}}$

while, $\sigma_{s}$ is the variance of the dataset.

\section{Results and Discussion}

The trend analysis is performed at different time scales for each rainfall station in Flores Island depending on the data available in the station. The average rainfall of the area (Flores Island or Sikka Regency) is estimated based on the recorded rainfall data in each station by considering the same duration in the records using arithmetic average.

Using average daily rainfall in Manggarai Barat, Sikka Regency, and Flores Timur Stations, the simple linear regression is performed to observe the daily rainfall in Flores Island. It reveals that no trend during $1998-2016$ of daily rainfall can be observed in the island (Figure 2). However, the plot reveals the annual variability of daily rainfall to have a similar pattern during the 20-year period where the peak of daily rainfall occurred in the first quarter of every year. An anomaly of extreme daily rainfall is observed to be much higher in 2001 and 2002, which exceeded $80 \mathrm{~mm} /$ day compared to the other years which on average is about $60 \mathrm{~mm} /$ day.

The simple linear regression is also performed for individual months during the year. An increasing trend of monthly rainfall is detected in nine of twelve months on the island during $1998-2016$ (Figure 3). The increment of mean monthly rainfall ranges from about $5 \mathrm{~mm}$ to more than $30 \mathrm{~mm}$ which occurs at most months in the rainy season on the island. 


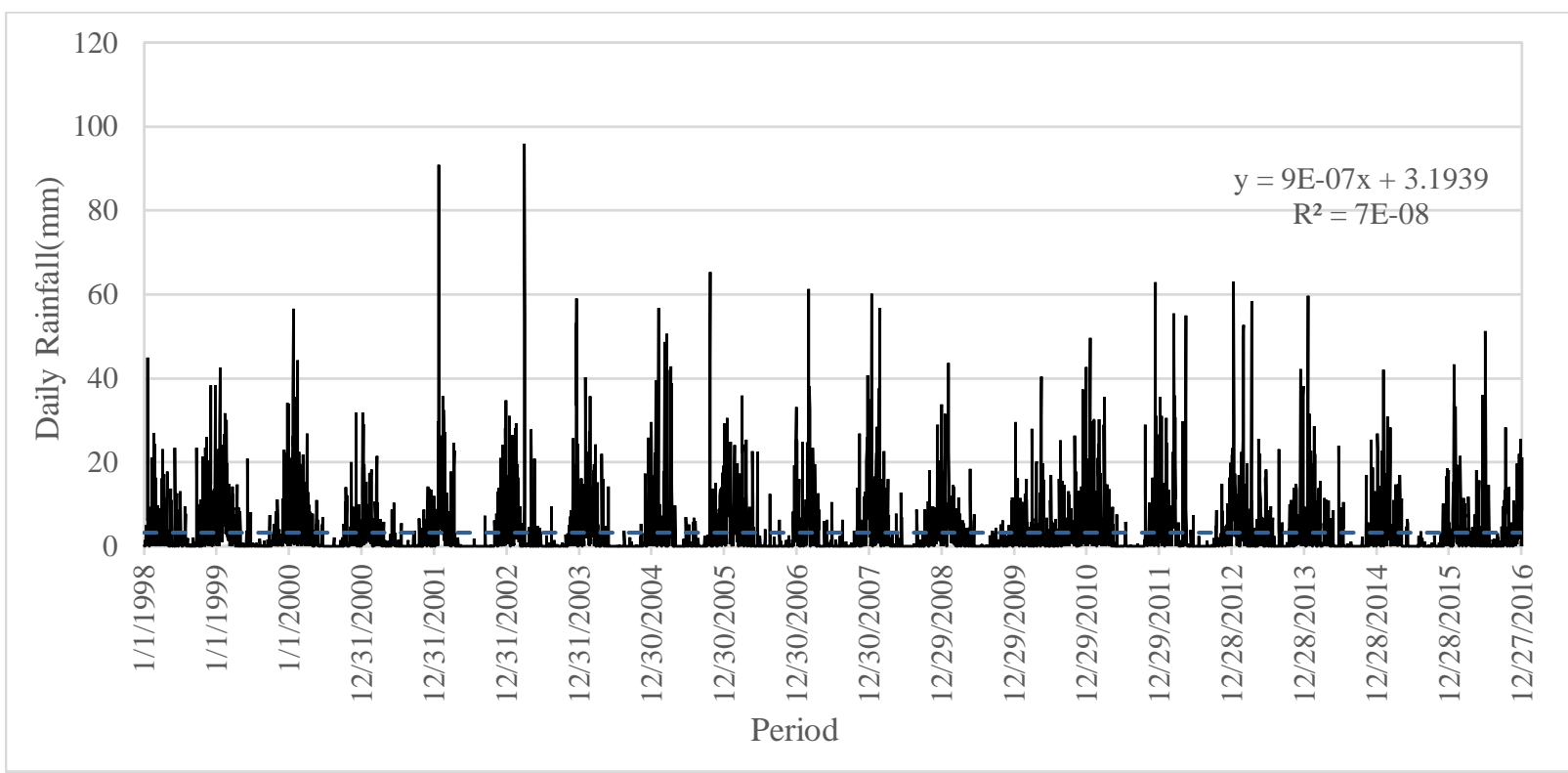

Figure 2. Trend of Daily Rainfall in Flores Island during 1998 - 2016
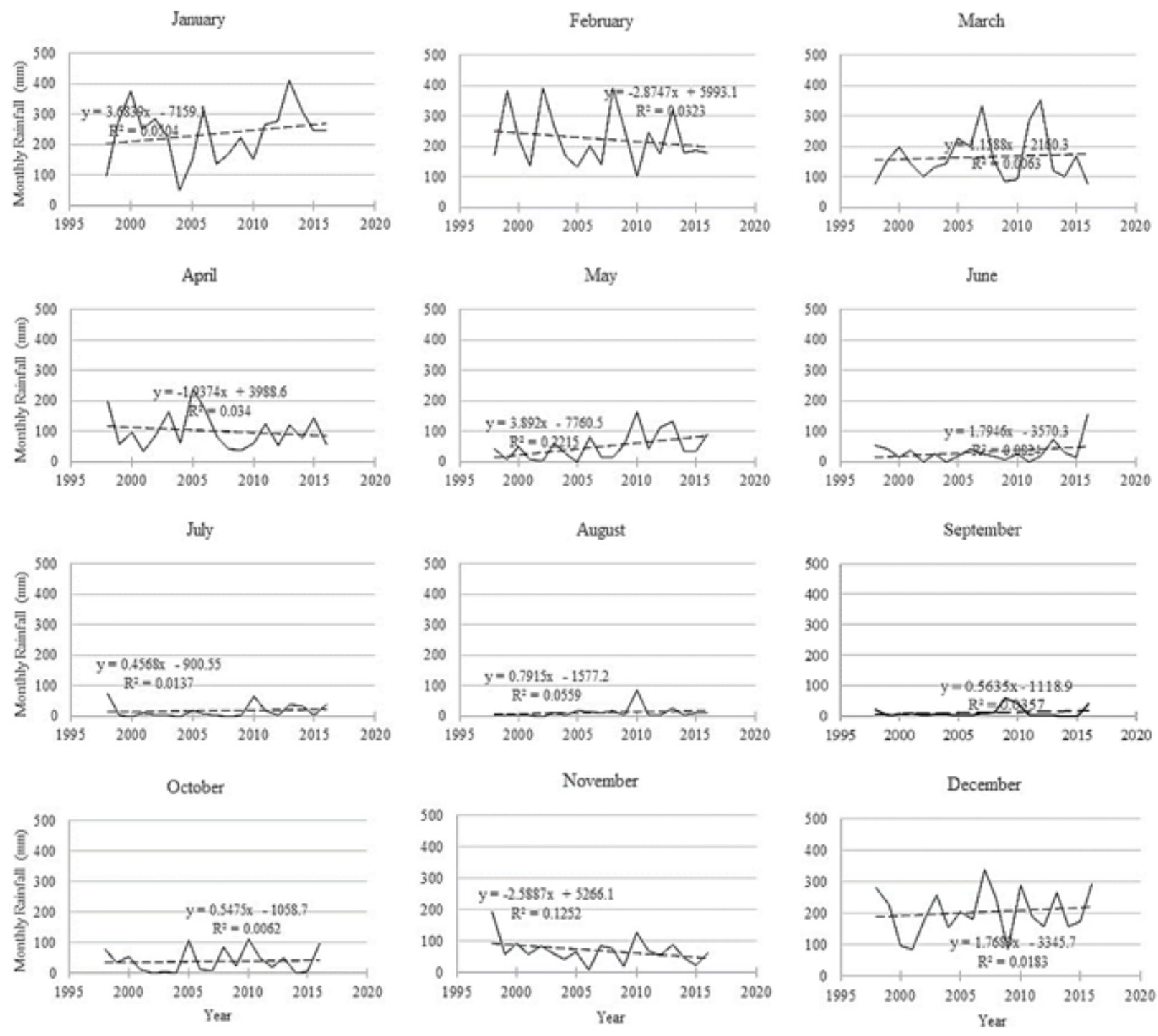

Figure 3. Trend of Monthly Rainfall in Flores Island during 1998 - 2016 
The simple linear regression model of annual rainfall in Flores Island confirmed that the increasing monthly rainfall in the island has contributed to the increased annual rainfall (Figure 4). The island received $70 \mathrm{~mm}$ of annual rainfall in 2016 higher than in the early years of 2000 .

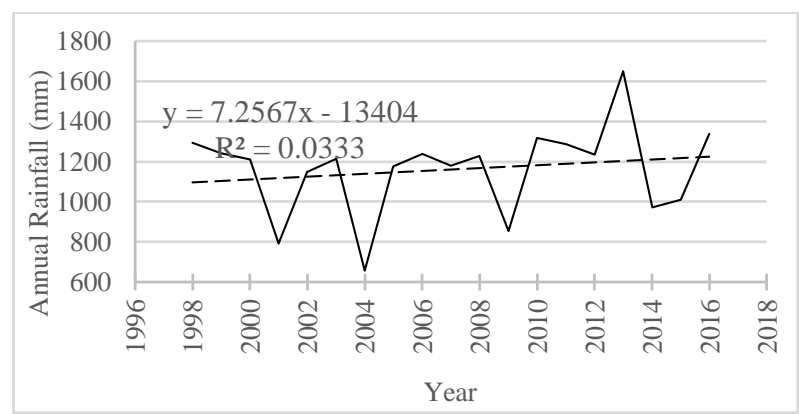

Figure 4. Trend of Annual Rainfall in Flores Island during $1998-2016$

T-test and Mann-Kendall's test are performed for individual stations operated by BMKG to observe the rainfall trend in each region in the island and for the middle part of the Island represented by the average value of rainfall from rainfall stations operated by the Agriculture Department of Sikka Regency (by considering the stations which have the same starting year and end year of record). All analysis is performed at 5\% significant level.

As described in the previous section, a longer period of daily rainfall data in Sikka Regency is available. The analysis of the stability of mean using t-test is performed at every 10-year time scale, i.e., two subsets between 1979-1998, 1989-2008, and 19992018 for monthly and annual rainfall using the average daily rainfall data from the Agriculture Department of Sikka Regency's rainfall stations. The change in mean of monthly and annual rainfall at each time scale is presented in Tables 1,2 , and 3. While the summary of the results of t-test during 1999 - 2018 in Flores Island is presented in Table 4.

Table 1. Change of Mean of Monthly and Annual Rainfall in Sikka Regency during 1979 - 1998

\begin{tabular}{|c|c|c|c|c|c|}
\hline & \multicolumn{2}{|c|}{ Mean of rainfall (mm) } & \multirow{2}{*}{$\begin{array}{c}\% \text { of } \\
\text { change }\end{array}$} & \multirow{2}{*}{ t-value } & \multirow{2}{*}{ Remarks } \\
\hline & $1979-1988$ & $1989-1998$ & & & \\
\hline Jan & 243.6 & 211.0 & -13.381 & -0.87 & $\mathbf{x}$ \\
\hline Feb & 237.5 & 223.1 & -6.044 & -0.442 & $\mathbf{x}$ \\
\hline Mar & 158.8 & 123.7 & -22.129 & -1.054 & $\mathbf{x}$ \\
\hline Apr & 63.1 & 116.7 & 84.865 & 1.947 & $\mathbf{x}$ \\
\hline May & 41.9 & 23.6 & -43.568 & -1.287 & $\mathbf{x}$ \\
\hline Jun & 19.3 & 22.5 & 16.296 & 0.418 & $\mathbf{x}$ \\
\hline Jul & 22.5 & 27.5 & 22.24 & 0.237 & $\mathbf{x}$ \\
\hline Aug & 3.3 & 5.4 & 62.63 & 1.016 & $\mathbf{x}$ \\
\hline Sept & 11.5 & 11.3 & -2.426 & -0.044 & $\mathbf{x}$ \\
\hline Oct & 33.2 & 32.2 & -3.062 & -0.073 & $\mathbf{x}$ \\
\hline Nov & 116.3 & 84.8 & -27.108 & -1.491 & $\mathbf{x}$ \\
\hline Dec & 197.0 & 187.1 & -5.027 & -0.219 & $\mathbf{x}$ \\
\hline Annual & 1148.0 & 1066.9 & -7.071 & -0.868 & $\mathbf{x}$ \\
\hline
\end{tabular}

Note: $t_{\text {critical }}=2.262 ; \mathbf{x}=$ not siginificant
Apparent from Tables 1 and 3, a decreasing mean in most months during the rainy season (October to April) in Sikka Regency is detected. On the other hand, a contrast result could be observed from Table 2 during the same season, a significant increasing trend is detected in March. Considering the time scale of the analysis stability of mean, it indicates the less rainfall occurs every 10-year.

It is noteworthy that most of the results of the stability of mean during 1979-2018 do not show any significant decreasing or increasing trend at any particular months, except in March during 19892008 which contributed to the significant increasing trend of annual rainfall in the region. Based on that particular observation, a further investigation to reveal the reason for the extreme contribution to the annual rainfall is suggested.

Table 2. Change of Mean of Monthly and Annual Rainfall in Sikka Regency during 1989 - 2008

\begin{tabular}{|c|c|c|c|c|c|}
\hline & \multicolumn{2}{|c|}{ Mean of rainfall (mm) } & \multirow{2}{*}{$\begin{array}{c}\% \text { of } \\
\text { change }\end{array}$} & \multirow{2}{*}{ t-value } & \multirow{2}{*}{ Remarks } \\
\hline & 1989-1998 & $1999-2008$ & & & \\
\hline Jan & 211.0 & 234.8 & 11.3 & 0.805 & $\mathbf{x}$ \\
\hline Feb & 223.1 & 277.4 & 24.3 & 1.228 & $\mathbf{x}$ \\
\hline Mar & 123.7 & 228.6 & 84.8 & 4.349 & $\checkmark$ \\
\hline Apr & 116.7 & 122.3 & 4.8 & 0.156 & $\mathbf{x}$ \\
\hline May & 23.6 & 27.6 & 17.0 & 0.338 & $\mathbf{x}$ \\
\hline Jun & 22.5 & 21.0 & -6.4 & -0.171 & $\mathbf{x}$ \\
\hline Jul & 27.5 & 7.2 & -73.7 & -1.382 & $\mathbf{x}$ \\
\hline Aug & 5.4 & 4.6 & -15.4 & -0.256 & $\mathbf{x}$ \\
\hline Sept & 11.3 & 4.7 & -58.3 & -1.632 & $\mathbf{x}$ \\
\hline Oct & 32.2 & 43.7 & 35.5 & 0.585 & $\mathbf{x}$ \\
\hline Nov & 84.8 & 89.4 & 5.5 & 0.252 & $\mathbf{x}$ \\
\hline Dec & 187.1 & 270.5 & 44.6 & 2.044 & $\mathbf{x}$ \\
\hline Annual & 1066.9 & 1331.9 & 24.8 & 4.617 & $\checkmark$ \\
\hline
\end{tabular}

Note: $t_{\text {critical }}=2.262 ; \mathbf{x}=$ not significant; $\checkmark=$ significant

Table 3. Change of Mean of Monthly and Annual Rainfall in Sikka Regency during 1999 - 2018

\begin{tabular}{lrrrrr}
\hline & \multicolumn{2}{c}{ Mean of rainfall $(\mathrm{mm})$} & \multicolumn{1}{c}{$\begin{array}{c}\text { \% of } \\
\text { change }\end{array}$} & t-value & Remarks \\
\cline { 2 - 5 } 1999-2008 $2009-2018$ & & & \\
\hline Jan & 234.8 & 250.0 & 6.4 & 0.380 & $\mathbf{x}$ \\
Feb & 277.4 & 218.0 & -21.4 & -1.915 & $\mathbf{x}$ \\
Mar & 228.6 & 171.6 & -24.9 & -1.864 & $\mathbf{x}$ \\
Apr & 122.3 & 109.9 & -10.1 & -0.351 & $\mathbf{x}$ \\
May & 27.6 & 62.7 & 126.7 & 2.028 & $\mathbf{x}$ \\
Jun & 21.0 & 24.4 & 15.9 & 0.352 & $\mathbf{x}$ \\
Jul & 7.2 & 17.7 & 145.6 & 1.272 & $\mathbf{x}$ \\
Aug & 4.6 & 12.4 & 171.5 & 1.469 & $\mathbf{x}$ \\
Sept & 4.7 & 21.1 & 349.6 & 1.397 & $\mathbf{x}$ \\
Oct & 43.7 & 37.7 & -13.7 & -0.269 & $\mathbf{x}$ \\
Nov & 89.4 & 86.4 & -3.4 & -0.147 & $\mathbf{x}$ \\
Dec & 270.5 & 198.5 & -26.6 & -1.956 & $\mathbf{x}$ \\
Annual & 1331.9 & 1210.3 & -9.1 & -1.761 & $\mathbf{x}$ \\
\hline
\end{tabular}

Note: $t_{\text {critical }}=2.262 ; \mathbf{x}=$ not significant

Careful attention is needed to be given at the time scale of the trend analysis. Data from a particular station, i.e., Sikka station, operated by BMKG was analysed at a 20-year period using simple linear regression and t-test. Both methods provide an agreement on showing an increasing trend during the rainy season in Sikka Regency. At a 10-year period of 
trend analysis, using the t-test, the average spatial values of rainfall are showing decreasing trend (Tables 1 and 3). In general, an insignificant decreasing trend is observed at 10-year time scale but on the contrary an insignificant increasing trend is observed at 20year time scale in Sikka Regency. In addition, a similar insignificant trend is also detected in western and eastern part of Flores Island during 1999-2018 as can be observed from Table 4 represented by Manggarai Barat and Flores Timur stations, respectively.

In accordance with the simple linear regression model and analysis stability of mean of Sikka Regency and Flores Island, insignificant increasing and decreasing trend of monthly and annual rainfall are detected when Mann-Kendall's test is performed (Tables 5 and 6). A significant increasing trend is particularly detected in July during 1999-2018 (Tables 5) and therefore, it confirms the increasing mean monthly rainfall in July (Table 3) which reaches 300\% in Sikka Regency. At a longer period (1979-2018), an increasing trend of monthly rainfall in the rainy season is observed in the Regency (Tables 5 and 6).

Table 4. Statistical t-value of Monthly and Annual Rainfall in Flores Island during 1999 - 2018

\begin{tabular}{lcccccc}
\multicolumn{2}{c}{ Station } & Manggarai Barat & \multicolumn{2}{c}{ Sikka } & \multicolumn{2}{c}{ Flores Timur } \\
\cline { 2 - 7 } Period & t-value Remarks & t-value Remarks & t-value & Remarks \\
\cline { 2 - 7 } Jan & -0.24 & $\mathbf{x}$ & -0.05 & $\mathbf{x}$ & 0.34 & $\mathbf{x}$ \\
Feb & -0.12 & $\mathbf{x}$ & 0.62 & $\mathbf{x}$ & -0.86 & $\mathbf{x}$ \\
Mar & -0.27 & $\mathbf{x}$ & 0.64 & $\mathbf{x}$ & 0.42 & $\mathbf{x}$ \\
Apr & -1.20 & $\mathbf{x}$ & 0.75 & $\mathbf{x}$ & -0.22 & $\mathbf{x}$ \\
May & 0.98 & $\mathbf{x}$ & 0.33 & $\mathbf{x}$ & 2.04 & $\mathbf{x}$ \\
Jun & 0.61 & $\mathbf{x}$ & -0.56 & $\mathbf{x}$ & 0.73 & $\mathbf{x}$ \\
Jul & 2.01 & $\mathbf{x}$ & -1.46 & $\mathbf{x}$ & -0.64 & $\mathbf{x}$ \\
Aug & 1.21 & $\mathbf{x}$ & -0.34 & $\mathbf{x}$ & 1.25 & $\mathbf{x}$ \\
Sept & 0.94 & $\mathbf{x}$ & -0.23 & $\mathbf{x}$ & 0.71 & $\mathbf{x}$ \\
Oct & 2.28 & $\mathbf{x}$ & 1.85 & $\mathbf{x}$ & 0.50 & $\mathbf{x}$ \\
Nov & -0.19 & $\mathbf{x}$ & -0.52 & $\mathbf{x}$ & -1.17 & $\mathbf{x}$ \\
Dec & 0.83 & $\mathbf{x}$ & 0.67 & $\mathbf{x}$ & 1.05 & $\mathbf{x}$ \\
Annual & 0.60 & $\mathbf{x}$ & 0.81 & $\mathbf{x}$ & 0.54 & $\mathbf{x}$ \\
\hline
\end{tabular}

Note: $t_{\text {critical }}=2.09 ; \mathbf{x}=$ not significant
Apart from the rainfall trend in Sikka Regency, Table 6 also reveals an increasing trend of monthly rainfall both in the rainy and dry seasons during a 20-year period in the eastern region of Flores Island represented by Flores Timur station. However, not any single month is showing a significant change during the last two decades.

Statistically, most of the changes of monthly and annual rainfall in Flores Island are not significant, however, the increasing trend of rainfall at a 20-year period during rainy season should be an alert. More rainfall might induce a positive impact to the region as it is known as a dry region, but without careful measures to adapt to the change, it might turn into a negative impact. Most importantly, due to the spatial inconsistency of rainfall trends in the island, more pre-cautious measures are needed to be taken.

\section{Conclusions}

The application of three statistical methods of trend analysis has resulted in the identification of an increasing trend of rainfall in the rainy season in Flores Island, particularly at a 20-year period. However, less rainfall at a 10-year period has been observed in Sikka Regency, the middle part of the island.

At a particular month of March 1989-2008, a significant increasing trend is detected, and it contributes to the significant increasing trend of annual rainfall in the same period. This knowledge should alert the possibility of the occurrence of extreme rainfall that might occur in the region. Therefore, for future work, the extreme rainfall pattern in the region should be investigated. Other methods to investigate the long-term variability of rainfall might also be employed for a better understanding.

Table 5. Mann-Kendall's Test Result on Trend of Monthly and Annual Rainfall in Sikka Regency

\begin{tabular}{cccccccccccccc}
\hline & Jan & Feb & Mar & Apr & May & Jun & Jul & Aug & Sept & Oct & Nov & Dec & Annual \\
\hline $1979-1998$ & - & - & - & + & - & + & + & + & - & + & - & + & - \\
$1999-2018$ & - & - & - & - & + & + & ++ & + & - & + & - & - & - \\
$1979-2018$ & + & + & + & + & - & + & + & + & - & + & - & + & + \\
\hline
\end{tabular}

Note: + = increasing trend; ++ = significant increasing trend; - = decreasing trend

Table 6. Mann-Kendall's Test Result on Trend of Monthly and Annual Rainfall in Flores Island

\begin{tabular}{|c|c|c|c|c|c|c|c|c|c|c|c|c|c|}
\hline & Jan & Feb & Mar & Apr & May & Jun & Jul & Aug & Sept & Oct & Nov & Dec & Annual \\
\hline Manggarai Barat ('98 -'16) & - & - & + & - & + & - & + & + & - & - & - & + & - \\
\hline Sikka $\left(77-16^{\prime}\right)$ & - & + & + & + & - & - & - & + & - & + & - & - & - \\
\hline Flores Timur ('98 -'16) & + & - & + & - & + & + & + & + & - & + & - & + & + \\
\hline
\end{tabular}

Note: + = increasing trend; - = decreasing trend 


\section{References}

1. Houghton, J.T., Filho, L.G.M., Callander, B.A., Harris, N., Kattenberg, A., and Maskell, K., Climate Change 1995: The Science of Climate Change: Contribution of Working Group I to the Second Assessment Report of the Intergovernmental Panel on Climate Change, Vol. 2, 1996: Cambridge University Press.

2. Solomon, S., Qin, D., Manning, M., Marquis, M., Averyt, K., Tignor M.M.B., Miller, Jr., H.L.M., and Chen, Z. , Climate Change 2007-the Physical Science Basis: Working Group I Contribution to the Fourth Assessment Report of the IPCC, Vol. 4, 2007: Cambridge University Press.

3. Aguilar, E., Barry, A.A., Brunet, M., Ekang, L., Fernandes, A., Massoukina, M., Mbah, J., Mhanda, A., do Nascimento, D.J., Peterson, T.C., Umba, O.T., Tomou, M., and Zhang, X., Changes in Temperature and Precipitation Extremes in Western Central Africa, Guinea Conakry, and Zimbabwe, 1955-2006. Journal of Geophysical Research, 114(D2), 2009.

4. Burn, D.H. and Elnur, M.A.H., Detection of Hydrologic Trends and Variability, Journal of Hydrology, 255(1), 2002, pp. 107-122.

5. De Luís, M., Raventós, J., González-Hidalgo, J.C., Sánchez, J.R., and Cortina, J., Spatial Analysis of Rainfall Trends in the Region of Valencia (east Spain), International Journal of Climatology, 20(12), 2000, pp. 1451-1469.

6. Kundu, S.K. and Mondal, T.K., Analysis of Longterm Rainfall Trends and Change Point in West Bengal, India, Theoretical and Applied Climatology, 138(3-4), 2019, pp. 1647-1666.

7. Kusumastuti, C. and Weesakul, S., Rainfall Pattern-Urbanization and Rainfall Pattern Change in Bangkok Metropolitan Administration, GWF Wasser Abwasser, 153(1), 2012, p. 74.

8. Manton, M.J., Della-Marta, P.M., Haylock, M.R., Hennessy, K.J., Nicholls, N., Chambers, L.E., Collins, D.A., Daw, G., Finet, A., Gunawan, D., Inape, K., Kestin, T.S., Lefale, P., Leyu, C.H., Lwin, T., Maitrepierre, L., Ouprasitwong, N., Page, C.M., Pahalad, J., Plummer, N., Salinger, M.J., Suppiah, R., Tran, V.L., Trewin, B., Tibig, I., and Yee, D., Trends in Extreme Daily Rainfall and Temperature in Southeast Asia and the South Pacific: 1961-1998, International Journal of Climatology, 21(3), 2001, pp. 269-284.

9. Modarres, R. and da Silva, V.P.R., Rainfall Trends in Arid and Semi-arid Regions of Iran, Journal of Arid Environments, 70(2), 2007, pp. 344-355.

10. Yepdo Djomou, Z.,Monkam, D., and Lenouo, A., Spatial Variability of Rainfall Regions in West Africa During the 20th Century, Atmospheric Science Letters, 10(1), 2008, pp. 9-13.
11. Zhang, X., Vincent, X. Z, Hogg, W.D., and Niitsoo, A., Temperature and Precipitation Trends in Canada during the 20 th Century, Atmosphere-Ocean, 38(3), 2000, pp. 395-429.

12. Taschetto, A.S. and England, M.H., An Analysis of Late Twentieth Century Trends in Australian Rainfall, International Journal of Climatology, 29(6), 2009, pp. 791-807.

13. Panthou, G., Lebel, T., Vischel T., Quantin, G., Sane, Y., Ba, A., Ndiaye, O., Diongue-Niang, A., and Diopkane, M., Rainfall Intensification in Tropical Semi-arid Regions: The Sahelian Case, Environmental Research Letters, 13(6), 2018, pp. 064013.

14. Kusumastuti, C. and Weesakul, S., Extreme Rainfall Indices for Tropical Monsoon Countries in Southeast Asia, Civil Engineering Dimension, 16(2), 2014, pp. 112-116.

15. Statistics Indonesia, Statistical Yearbook of Indonesia 2020, 2020, Indonesia: Statistics Indonesia.

16. Sub-directorate of Environment Statistics, Environment Statistics of Indonesia 2020, 2020, Statistics Indonesia: Indonesia.

17. Argaman, E., Barth, R., Mosche, Y., and BenHur, M., Long-term Effects of Climatic and Hydrological Variation on Natural Vegetation Production and Characteristics in a Semiarid Watershed: The northern Negev, Israel, Science of The Total Environment, 747, 2020, pp. 141-146.

18. Ogunrinde, A.T., Oguntunde, P.G., Akinwumiju, A.S., and Fasinmirin, J.T., Analysis of Recent Changes in Rainfall and Drought Indices in Nigeria, 1981-2015, Hydrological Sciences Journal, 64(14), 2019, pp. 1755-1768.

19. Piyoosh, A.K. and Ghosh, S.K., Identification and Analysis of Recent Temporal Temperature Trends for Dehradun, Uttarakhand, India, Meteorology and Atmospheric Physics, 131(4), 2019, pp. 863-882.

20. Heumann, C., Schomaker, M., and Shalabh, Introduction to Statistics and Data Analysis, 2016, Springer.

21. Kumar, N., Panchal, C.C., Chandrawanshi, S.K., and Thanki, J.D., Analysis of Rainfall by using Mann-Kendall Trend, Sen's Slope and Variability at Five Districts of South Gujarat, India, Mausam, 68, 2017, pp. 205-222.

22. Zhang, Q., Liu, C., Xu, C., Xu, Y., and Jiang, T., Observed Trends of Annual Maximum Water Level and Streamflow during Past 130 Years in the Yangtze River basin, China, Journal of Hydrology, 324(1), 2006, pp. 255-265.

23. Kallache, M., Rust, H.W., and Kropp, J., Trend Assessment: Applications for Hydrology and Climate Research, 2005.

24. Nalley, D., Adamowski, J., Khalil, B., and OzgaZielinski, B., Trend Detection in Surface air Temperature in Ontario and Quebec, Canada 
during 1967-2006 using the Discrete Wavelet Transform, Atmospheric Research, 132-133, 2013, pp. 375-398.

25. Wang, Y., Youpeng, X. Tabari, H., Wang, J., Wang, Q., Song, S., and Hu, Z., Innovative Trend Analysis of Annual and Seasonal Rainfall in the Yangtze River Delta, Eastern China, Atmospheric Research, 2020, 231.

26. Ghasemi, A.R., Changes and Trends in Maximum, Minimum and Mean Temperature Series in Iran, Atmospheric Science Letters, 16(3), 2015, pp. 366-372. 